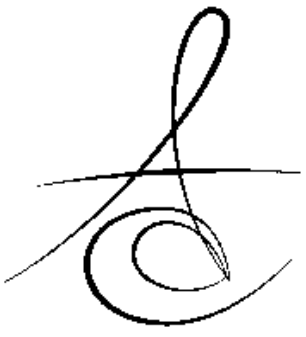

\section{RADIOGRAPHIC FEATURES OF SUPERNUMERARY TEETH IN THE SOUTHERN TURKISH INDIVIDUALS}

\author{
GÜNEYLİ TÜRK BİREYLERDE SÜPERNÜMERE DİŞLERİN RADYOGRAFİK \\ ÖZELLİKLERİ
}

Arş. Gör. Dr. Hümeyra TERCANLI ALKIŞ*

Dr. Öğr. Üyesi Sevcihan GÜNEN YILMAZ

Makale Kodu/Article code: 3474

Makale Gönderilme tarihi: 17.08.2017

Kabul Tarihi: 19.04.2018

\section{ABSTRACT}

Aim: The aim of this study was to assess radiographic features of supernumerary teeth and demographic factors of Southern Turkish individuals.

Material and Method: Retrospectively; panoramic radiographs of 3713 randomly selected individuals were analyzed by two oral radiologists based on the presence of supernumerary teeth. Chi-square test was performed for comparing the frequency of supernumerary teeth between female and male patients. $p<0.05$ was accepted statistically significant.

Results: Twenty-nine (0.78\%) of the 3713 individuals had one and more supernumerary teeth $(22,6$, and 1 patients had one, two and three supernumerary teeth, respectively). Of these 29 individuals, 16 were female and 13 were male. Total of 37 supernumerary teeth were found and mandibula $(n=21)$ was more frequently than maxilla $(n=16)$. There was not statistically significant difference in the distribution according to the genders.

Conclusions: The evaluation of 3713 panoramic radiographs revealed a prevalence of supernumerary teeth of $0.78 \%$. Supernumerary teeth were more common in the mandibula than in the maxilla, and there was not statistically significant difference in the gender disturbance.

Key words: Supernumerary Teeth; Prevalence; Panoramic Radiography

\section{öz}

Amaç: Bu çalışmanın amacı Güneyli Türk bireylerde süpernümere dişlerin radyografik özelliklerini ve demografik faktörlerini değerlendirmektir.

Gereç ve Yöntem: Rastgele seçilen bireylerden elde edilen 3713 adet panoramik radyografi süpernümere diş varlığı açısından iki radyolog tarafından retrospektif olarak analiz edildi. Kadın erkek arasındaki süpernümere diş sıklığını kıyaslamak amacıyla ki kare testi uygulandı. $\mathrm{p}<0.05$ istatistiki olarak önemli sayıldı.

Bulgular: 3713 bireyin 29'unda (0.78\%) bir veya daha fazla süpernümere diş vardı $(22,6$, ve 1 bireyde sırasıyla bir, iki ve üç süpernümere diş). 29 hastadan 16 'sı kadın ve 13 'ü erkekti. Toplam 37 süpernümere diş bulundu ve mandibulada (21 adet) süpernümere diş sıklığı maksilladan (16 adet) daha fazla bulundu. Cinsiyete göre dağılımda istatistiksel olarak anlamlı fark yoktu.

Sonuç: 3713 panoramik radyografi değerlendirmesi sonucu süpernümere diş prevelansı $0.78 \%$ olarak bulundu. Süpernümere diş mandibulada maksilladan daha sıktı ve cinsiyet dağılımında istatiksel bir farklılık bulunamadı.

Anahtar Kelimeler: Süpernümere Dişler; Prevelans; Panoramik Radyografi

\footnotetext{
* Akdeniz Üniversitesi Diş Hekimliği Fakültesi, Ağız, Diş ve Çene Radyolojisi A.D, Antalya.
} 


\section{INTRODUCTION}

Supernumerary teeth or hyperdontia refers to an extra tooth, teeth, or tooth-like structures additionally the 20 deciduous and 32 permanent teeth. ${ }^{1}$ Supernumerary teeth can be simple or multiple forms. They may be unilateral or bilateral and erupted or unerupted. In addition that they can appear one or both jaws. ${ }^{1-5}$

Several theories about the etiology of supernumerary teeth have emerged, but the main etiology remains unclear. The most common opinion is that supernumerary teeth develop in consequence of horizontal proliferation or hyperactivity of the dental lamina. ${ }^{2,}$ 4-7 Some studies suggested that the main etiological factor is genetic predisposition related to a disorder associated with a dominant autosomal gene. ${ }^{2,}$ 8 According to other literature, supernumerary teeth are an autosomal recessive feature with incomplete penetrance, or they may be related with the $X$ chromosome. $^{8}$

Supernumerary teeth may be related to varied syndromes like Ehlers-Danlos syndrome, Gardner's syndrome, Apert Syndrome, cleidocranial dysplasia and Down's syndrome. Supernumerary teeth associated with these syndromes often appear in multiple forms ${ }^{9}$, but they may also occur in patients without such syndromes. ${ }^{3,6}$

Supernumerary teeth are not always cause any side effects on the adjacent teeth. ${ }^{5}$ Nevertheless, they can responsible root resorption, delayed or abnormal root development, displacement or rotation of the adjacent teeth, eruption failure, crowding, malocclusion, dilacerations, fistulas and cystic formation. $^{8}$

They can be classified as conical, tuberculate, supplemental, and odontomas according to their morphology. ${ }^{3}$ Most frequently, supernumerary teeth are conical and are generally presented as mesiodens. The tuberculate shape usually exceeds the size of the conical form. The root is largely incomplete or completely missing. ${ }^{4}$ If supernumerary teeth resemble normal morphology, they are called supplemental teeth. Supplemental teeth are commonly encountered among the mandibulary distomolars. ${ }^{5}$

Based on location, supernumerary teeth that take place between the central incisors are called as mesiodens teeth, those situated bucally or lingually to a molar tooth are refered to paramolar teeth, and those especially located distally to the third molar are called distomolar teeth. ${ }^{4,5,10}$ The other teeth are identified to according their located region ${ }^{4,10}$; they may be vertical, inverted, or transversal orientations. ${ }^{2}$

Supernumerary teeth may have various forms and occur in both dentitions. ${ }^{5,6,9}$ Supernumerary permanent teeth are more common than supernumerary primary teeth. ${ }^{5,8}$ The frequency of supernumerary teeth in permanent dentition is five times higher than that in primary dentition. ${ }^{11}$

Supernumerary teeth do not usually show sexual predilection in deciduous dentition ${ }^{3}$, but sexual predilection in permanent dentition has been reported by researchers. ${ }^{5}$ This condition is two times more common among men than women in permanent dentition. $^{2-4,7,9,11,12}$

This anomaly affects the maxilla more often than the mandible. ${ }^{2}$ 5, 8,13 In deciduous dentition, supernumerary teeth are mostly encountered in the maxillary incisor region ${ }^{4,14}$, whereas they are commonly found on the maxillary midline in permanent dentition. These teeth can also be found in maxillary fourth molars, maxillary lateral incisors, mandibular fourth molars, and mandibular central incisors. $^{5,10}$

Supernumerary teeth prevalence in permanent and deciduous dentition is from $0.3 \%$ to $0.8 \%$ and from $1.5 \%$ to $3.5 \%$, respectively. ${ }^{2,5}$ The frequency of supernumerary teeth is reported to be between $0.1 \%$ and $3.8 \%$ in the general population. ${ }^{6}$, 15,16

This study aimed to assess radiographic features of supernumerary teeth and demographic factors of Turkish individuals who were admitted the Department of Dentomaxillofacial Radiology, Faculty of Dentistry, Akdeniz University.

\section{MATERIALS and METHOD}

This retrospective study was conducted in 3713 individuals who were admitted to Department of Dentomaxillofacial Radiology, Faculty of Dentistry, Akdeniz University by two oral radiologists based on the presence of supernumerary tooth. Digital panoramic radiographs were obtained with a panoramic device (Planmeca Oy, Helsinki 00880, Finland). 
In this study informations about the demographic variables including age and gender for each patient were collected. Individuals under 6 years of age were excluded the study. The study was carried out in deciduous and permanent dentition. The image quality was not good, and teeth which may be odontoma were not included in the study.

Supernumerary teeth were classified according to four categories, namely, location (maxilla or mandible, left or right quadrant), position (vertical, horizontal, angled or inverted), morphology (conical, tuberculated, supplemental) and eruption (erupted or unerupted). Descriptive statistical analysis was performed. To compare differences between male and female patients, Pearson's correlation test was performed and $\mathrm{p}<0.05$ was acknowledged statistically meaningful. Radiographs with supernumerary teeth were reevaluated for correlation between observers and Intraclass Correlation Coefficient test was applied.

\section{RESULTS}

Twenty-nine of 3713 individuals had one and more supernumerary teeth. Of these 29 patients, 13 were male $(44,8 \%)$ and 16 were female $(55,2 \%)$. A total of 37 supernumerary teeth were identified. The female to male ratio was $1: 0.8$. There was no statistically significant difference in the distribution according to the genders $(p=0.46)$. The prevalence of supernumerary teeth was $0.78 \%$. Intraclass Correlation Coefficient was $>90 \%$.

There were $21(56.76 \%)$ and $16(43.24 \%)$ supernumerary teeth in the mandibula and maxilla, respectively. Male patients had four supernumerary teeth in the maxilla, which presented as two supernumerary tooth in the left quadrant side and the others in the right quadrant side. In addition, male patients had thirteen supernumerary teeth in the mandibula (seven in the right quadrant side and six in the left quadrant side). Female patients had twelve supernumerary teeth in the maxilla and eight supernumerary teeth in the mandibula. They had seven supernumerary teeth in the maxillary right quadrant side and five supernumerary teeth in the maxillary left side quadrant. Moreover, they had three supernumerary teeth in the mandibular right quadrant side and five supernumerary teeth in the mandibular left quadrant side (Table 1). There were seven (18.92\%) supernumerary teeth in the anterior region, $16(43.24 \%)$ supernumerary teeth in the premolar region, and $14(37.84 \%)$ supernumerary teeth in the molar region. In the anterior region, one tooth was mesiodens. In the posterior region, three (21.43\%) teeth were paramolar and eleven $(78.57 \%)$ teeth were distomolar. Three patients $(10.34 \%)$ exhibited a supernumerary tooth in mixed dentition, and other supernumerary teeth were in permanent dentition. In mixed dentition, one supernumerary tooth was in the maxillary right quadrant side, one supernumerary tooth was in the mandibular right quadrant side, and one supernumerary tooth was in the mandibular left quadrant side.

Table 1. Value of Pearson Chi-Square test and numbers of maxillar right, left and mandibular right, left supernumerary teeth

\begin{tabular}{ccccccccc}
\hline & \multirow{2}{*}{$N$} & \multicolumn{2}{c}{ Maxilla } & \multicolumn{3}{c}{ Mandible } & Total & \multirow{2}{*}{$\mathrm{P}^{*}$} \\
\cline { 3 - 7 } & & Right & Left & Right & Left & & \\
\hline Female & 16 & 7 & 5 & 3 & 5 & 20 & \\
Male & 13 & 2 & 2 & 7 & 6 & 17 & 0.46 \\
Total & \multicolumn{7}{c}{16} & \multicolumn{2}{c}{21} & & & \\
\hline
\end{tabular}

$\mathrm{N}$, Number of patients; a, value of Pearson Chi-Square test

${ }^{*}$,This result is not significant at $\mathrm{p}<.05$.

Twenty-one (56.75\%) supernumerary teeth were in the vertical position, eight (21.62\%) supernumerary teeth were in an angled position, six (16.23\%) supernumerary teeth were in the horizontal position, and two (5.4\%) supernumerary teeth were in an inverted position.

In terms of morphology, four (10.81\%) supernumerary teeth were conical, 17 (45.95\%) supernumerary teeth were tuberculated, and 16 (43.24\%) supernumerary teeth were supplemental (Graphic $1 \mathrm{~A}$ and $1 \mathrm{~B}$ ).

Of the 37 supernumerary teeth, 35 (94.59\%) supernumerary teeth were unerupted and two $(5.41 \%)$ supernumerary teeth were erupted. 


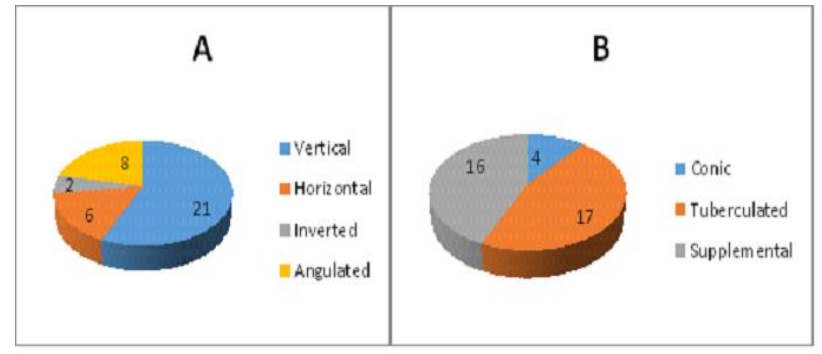

Graphic 1. A. Number of supernumerary teeth according to their positions

B. Number of supernumerary teeth according to their morphology

Twenty-two $(75.86 \%)$ patients had a single supernumerary tooth, six (20.69\%) patients had two supernumerary teeth, and one (3.45\%) patient had three supernumerary teeth (Graphic 2). Patients with multiple supernumerary teeth did not have any of the aforementioned syndromes. Three patients had eruption problems depending on supernumerary teeth.

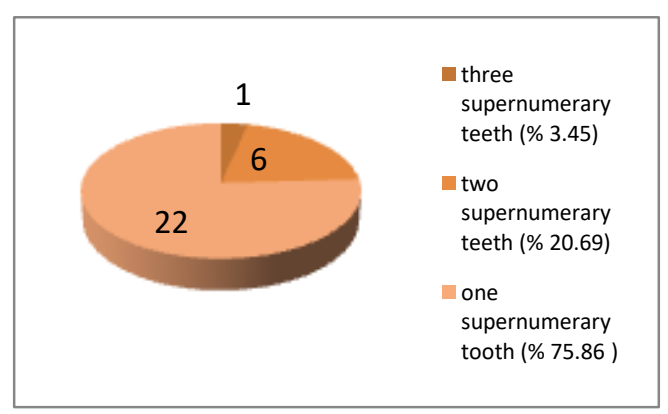

Graphic 2. Supernumerary teeth distribution

\section{DISCUSSION}

Supernumerary teeth (hyperdontia) refer to an extra tooth or teeth, and they are infrequent developmental alterations. They may be formed alone or in multiples in any part of the jaws in the same person. ${ }^{6}$

Previous studies demonstrated that supernumerary teeth are more common among men than women. $2-4,7,9,11,12$ In this study, female/male ratio was $1: 0.8$, and the difference was not statistically significant.
In the general population, the prevalence of supernumerary teeth is reported to be between $0.1 \%$ and $3.8 \% .^{6}$ In the current study, this prevalence among 3713 patients was $0.78 \%$ in Antalya. Our findings were similar to results reported by other studies. According to Kara et al. ${ }^{5}$ the prevalence of supernumerary molars is $0.33 \%$ in seven different cities in Turkey, and Demiriz et al. ${ }^{6}$ demonstrated a prevalence of $2.14 \%$ among 7,348 patients in Zonguldak. Singh et al. $^{3}$ found the prevalence of supernumerary teeth in 2864 Nepalese patients is $1.60 \%$. Mahabob et al. ${ }^{11}$ and Kashyap et al. ${ }^{1}$ revealed a prevalence of $1.2 \%$ in a South Indian population. Casetta et al. ${ }^{4}$ reported a prevalence of $0.18 \%$ in molars in an Italian population. Kumar et al. ${ }^{9}$ found a prevalence of $1.56 \%$ in an India population. This variability may be due to the different age groups that were examined. ${ }^{9}$

Supernumerary teeth may be categorized according to morphology and location ${ }^{3}$, and they are found less frequent in the mandibula than in the maxilla. In 2000, Menardía-Pejuan et al. ${ }^{17}$ reported that $86.8 \%$ of supernumerary teeth affect the maxilla, whereas Kara et al. $^{5}$ reported $87.7 \%$ of supernumerary teeth in the maxilla. In the present study, $43.24 \%$ of the supernumerary teeth were located in the maxilla, and $56.76 \%$ were located in the mandible. These findings were inconsistent with the literature. According to Kumar et al. ${ }^{9}$, the highest prevalence is in the premolar region $(37.5 \%)$, incisor region follow this $(25.8 \%)$ and the least prevalence in the molar region (12.5\%). The prevalence of the premolar region was consistent with the results of this study, whereas that of the molar and incisor region was inconsistent with this study. The present study represented that the highest prevalence of supernumerary teeth was in the premolar region $(43.24 \%)$, molar region follow this $(37.84 \%)$ and the least prevalence in the incisive region (18.92\%).

Approximately $56.75 \%$ of the supernumerary teeth were at the vertical position, followed by the angled position $(21.62 \%)$. This finding had similar results like Demiriz et.al. ${ }^{6}$ In addition, the prevalence of supernumerary teeth at the horizontal and inverted positions was $16.23 \%$ and $5.4 \%$, respectively.

Several studies demonstrated that the supernumerary tooth of conical morphology is the most common occurrence among all morphological

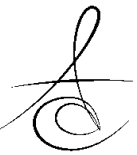


types ${ }^{2}$, followed by tuberculate and supplementary teeth. ${ }^{2}$ 5, 18 However, this finding was inconsistent with the present study. Our results indicated that the most common supernumerary teeth were tuberculate (45.95\%), followed by supplemental (43.24\%) and conical $(10.81 \%)$ forms. Although odontoma may be considered a type of defective tooth development, it is frequently designated as an evolutive tumor. ${ }^{5}$ Thus, we did not include odontomas in our study like Kara et al. $^{5}$

Supernumerary teeth, whether impacted or erupted, may remain in position for years without causing any disturbances and clinical manifestations. ${ }^{1}$ However, in some cases, they may cause some problems in neighboring teeth such as root resorption, delayed or abnormal root development, rotation or displacement of the adjacent teeth, dilacerations, eruption failure, crowding, malocclusion, fistulas and cystic formation. ${ }^{8}$ In the present study, one patients experienced eruption failure due to supernumerary teeth (Figure 1).

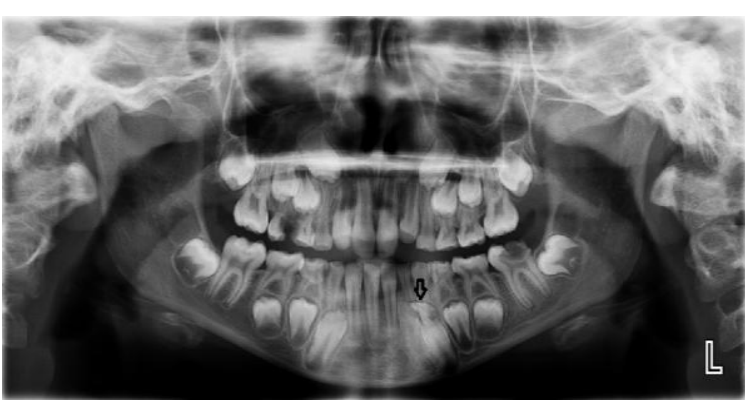

Figure 1. A supernumerary tooth preventing the erupsion of left mandibular lateral tooth

It is the shown that the prevalence of single supernumerary teeth in $76 \%-86 \%$, the prevalence of double supernumeraries in $12 \%-23 \%$, and the prevalence of multiple supernumeraries in $<1 \%$ of cases. ${ }^{1}$ In this study, we found that the prevalence of single supernumerary tooth was $75.86 \%(n=22)$, whereas that of double supernumerary teeth was $20.69 \%(n=6)$. In addition, one patient had three supernumerary teeth.

In the literature, some researchers reported that multiple supernumerary teeth are associated with several syndromes. ${ }^{3,6}, 19$ However, these teeth may also occur in patients without such syndromes. In the present study, patients with multiple supernumerary teeth did not have any of the aforementioned syndromes.

Supernumerary teeth may be seen in both primary and permanent dentition, but the incidence in deciduous dentition is lower than that in permanent dentition. ${ }^{19}$ In this study, three patients $(10.34 \%)$ had supernumerary tooth in mixed dentition and other supernumerary teeth were in permanent dentition.

Supernumerary teeth are diagnosed accidenttally during intraoral or radiological examination. ${ }^{5,11}$ Given that this study was a retrospective one, we do not know whether the supernumerary teeth were detected by chance or a result of patient complaint.

This condition can be treated in several ways: (1) If complications are present, anticipated removal of the supernumerary teeth is recommended; (2) If the teeth are asymptomatic and have no associated pathology, the supernumerary teeth are left in situ with periodic follow up. ${ }^{1}$

\section{CONCLUSIONS}

The evaluation of 3713 panoramic radiography obtained from individuals revealed that the prevalence of supernumerary teeth was $0.78 \%$ among our cases. Moreover, we found that supernumerary teeth were more common in the mandibula than in the maxilla. The most common supernumerary teeth were tuberculate in our study, followed by supplemental and conical forms. The highest prevalence of supernumerary teeth was in the premolar region, whereas intermediate prevalence was found in the molar region. The least prevalence of supernumerary teeth was in the incisive region. According to orientations, the most common supernumerary teeth were vertical, followed by angled, horizontal, and inverted positions. No statistically significant difference was found between genders.

Hümeyra Tercanlı Alkış ORCID ID: 0000-0003-0869-875X Sevcihan Günen Yılmaz ORCID ID: 0000-0002-4566-2927

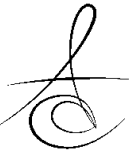




\section{REFERENCES}

1. Kashyap RR, Kashyap RS, Kini R, Naik V. Prevalence of hyperdontia in nonsyndromic South Indian population: An institutional analysis. Indian J Dent 2015; 6: 135-8.

2. Ata-Ali F, Ata-Ali J, Penarrocha-Oltra D, Penarrocha-Diago M. Prevalence, etiology, diagnosis, treatment and complications of supernumerary teeth. J Clin Exp Dent 2014; 6: 414-8.

3. Singh VP, Sharma A, Sharma S. Supernumerary teeth in Nepalese children. ScI World J 2014; 2014 : 215396.

4. Cassetta M, Altieri F, Giansanti M, Di-Giorgio R, Calasso S. Morphological and topographical characteristics of posterior supernumerary molar teeth: an epidemiological study on 25,186 subjects. Med Oral Patol Oral Cir Bucal 2014; 19: 545-9.

5. Kara MI, Aktan AM, Ay S, Bereket C, Sener I, Bulbul M, Ezirganli S, Polat HB. Characteristics of 351 supernumerary molar teeth in Turkish population. Med Oral Patol Oral Cir Bucal 2012; 17: 395-400.

6. Demiriz L, Durmuslar MC, Misir AF. Prevalence and characteristics of supernumerary teeth: A survey on 7348 people. J Int Soc Prev Community Dent 2015; 5: 39-43.

7. Cassetta M, Altieri F, Di Mambro A, Galluccio G, Barbato $E$. Impaction of permanent mandibular second molar: a retrospective study. Med Oral Patol Oral Cir Bucal 2013; 18: 564-68.

8. Subasioglu A, Savas S, Kucukyilmaz E, Kesim S, Yagci A, Dundar M. Genetic background of supernumerary teeth. Eur J Dent 2015; 9: 153- 8.

9. Kumar DK, Gopal KS. An epidemiological study on supernumerary teeth: a survey on 5,000 people. J Clin Diagn Res 2013; 7: 1504- 7.

10. De Oliveira Gomes C, Drummond SN, Jham BC, Abdo EN, Mesquita RA. A survey of 460 supernumerary teeth in Brazilian children and adolescents. Int J Paediatr Dent 2008; 18: 98-106.

11. Mahabob MN, Anbuselvan GJ, Kumar BS, Raja S, Kothari S. Prevalence rate of supernumerary teeth among non-syndromic South Indian population: An analysis. J Pharm Bioallied Sci 2012; 4: 373-5.
12. Mercuri E, Cassetta M, Cavallini C, Vicari D, Leonardi R, Barbato E. Dental anomalies and clinical features in patients with maxillary canine impaction. Angle Orthod 2013; 83: 22-8.

13. Shah A, Gill DS, Tredwin C, Naini FB. Diagnosis and management of supernumerary teeth. Dent Update 2008; 35: 510-2, 514-6, 519-520.

14. Solares R, Romero MI. Supernumerary premolars: a literature review. Pediatr Dent 2004; 26: 450-8.

15. Celikoglu M, Kamak H, Oktay $H$. Prevalence and characteristics of supernumerary teeth in a nonsyndrome Turkish population: associated pathologies and proposed treatment. Med Oral Patol Oral Cir Bucal 2010; 15: 575-8.

16. Kuchler EC, Costa AG, Costa Mde C, Vieira AR, Granjeiro JM. Supernumerary teeth vary depending on gender. Braz Oral Res 2011; 25: 76-9.

17. Menardia-Pejuan V, Berini-Aytes L, Gay-Escoda C. Supernumerary molars. A review of 53 cases. Bull Group Int Rech Sci Stomatol Odontol 2000; 42: 101-5.

18. Ramesh K, Venkataraghavan K, Kunjappan S, Ramesh M. Mesiodens: A clinical and radiographic study of 82 teeth in 55 children below 14 years. J Pharm Bioallied Sci 2013; 5: 60-2.

19. Över H, Uysal İ, Çetinkaya M. Meziodenslerin Değerlendirilmesi: Klinik ve radyografik bir çalışma. Atatürk Üniv. Diş Hek. Fak. Derg 2012; 22: 120-4.

\author{
Yazışma Adresi \\ Dr.Hümeyra TERCANLI ALKIŞ \\ Akdeniz Üniversitesi, \\ Diş Hekimliği Fakültesi, \\ Ağız,Diş ve Çene Radyolojisi Anabilim Dalı, \\ 07058/ Antalya,TÜRKİYE \\ Tel: +90 2422274400 \\ Fax: +90 2423106967 \\ E-mail: ysl hmyr25@hotmail.com
}

